\title{
Certification of Fisheries Human Rights and Its Impact to Protecting the Rights of Fishing Vessel Crew
}

\author{
Muhammad Nur ${ }^{2 *}$, M. Hajir Susanto ${ }^{2}$
}

1,2 Faculty of Law, Universitas Ahmad Dahlan, Bantul, Daerah Istimewa Yogyakarta, 55191, Indonesia

* Corresponding author email address: muhammad.nur@law.uad.ac.id

\begin{tabular}{|c|c|}
\hline Article & Abstract \\
\hline $\begin{array}{l}\text { Article History } \\
\text { Received: Nov 30, 2020; } \\
\text { Reviewed: Dec 02, 2020; } \\
\text { Accepted: Jan 11, 2021; } \\
\text { Published: Feb 11, } 2020\end{array}$ & $\begin{array}{l}\text { The crew of fishing vessels is human beings, the absolute owners of buman rights } \\
\text { that have been universally recognized. To anticipate and overcome many human } \\
\text { rights violations in the Indonesian seas, the Government, through the Ministry of } \\
\text { Marine Affairs and Fisheries issued a Regulation of the Minister of Marine } \\
\text { Affairs and Fisheries Number } 35 \text { of } 2015 \text { concerning Fisheries Human Rights } \\
\text { Systems and Certification. This research further describes how the provisions of the } \\
\text { fisheries' buman rights certification and analyses their impact on protecting human } \\
\text { rights for fishing vessel crews in Indonesia. The author uses a normative juridical } \\
\text { research method by examining library materials or other secondary materials. The } \\
\text { data collection method used is a literature study. The tools used are documents in } \\
\text { the form of primary, secondary, and non-legal legal materials. The data obtained } \\
\text { were analysed qualitatively and then presented descriptively. This study found that } \\
\text { there are various forms of human rights violations against fishing boat crews. } \\
\text { Ministry of Marine Affairs and Fisheries then enforces regulation to prevent } \\
\text { buman rights violations by business actors against fishing vessel crews. There are } \\
\text { several weaknesses in regulations and implementations, namely weaknesses in wage } \\
\text { system arrangements, limited regulatory targets, the involvement of workers and } \\
\text { employers' representatives in the fisheries human rights team that is not clear, } \\
\text { weaknesses of the coordinating system for fisheries human rights teams with } \\
\text { supervisor's employment, weaknesses of fisheries human rights assessment } \\
\text { institutions, weaknesses of socialization for employers and workers. The author } \\
\text { suggests that it is necessary to strengthen the coordination and cooperation system } \\
\text { between ministries in implementing Fisheries Human Rights Regulations. It also } \\
\text { needs to improve communication and dissemination of policies and regulations to } \\
\text { stakeholders. }\end{array}$ \\
\hline
\end{tabular}

(C)2021; This is an Open Acces Research distributed under the term of the Creative Commons Attribution License (https://Creativecommons.org/licences/by/4.0), which permits unrestricted use, distribution, and reproduction in any medium, provided the original works is properly cited. 


\section{INTRODUCTION}

One of the most important elements in the capture fisheries business is workers who work as crew members on the capture fishing vessels (Wijaya \& Firdaus, 2016). Crew members who work on fishing vessels in various areas, especially in coastal areas, often travel long distances and undertake heavy work to ensure financial security and achieve a better future for themselves and their families. Their tireless efforts by working on fishing vessels not only support them but also contribute to the country's food security as well as the country's economic development. However, these benefits are not easy to obtain. The crew's struggle on this fishing vessel in its implementation has posed a serious threat to their safety. The International Labor Organization (ILO) has identified commercial fishing as hazardous work with a very high accident and death rate in the world (International Labour Organization, 2013).

The broad coverage of the working area causes fishing vessels to vary considerably in length or duration. Apart from that, the duration of the fishing vessels' journey also depends on the vessels' size, the fishing season, or other factors such as the changing weather. Small ships usually sail for only one day (one-day fishing), while large ships can reach up to months (Suwardjo et al., 2017). It is also usually adjusted to the number of supplies and fuel prepared on the fishing vessel. The ILO states that capture fisheries business is the most vulnerable business sector to human rights violations because it is far from the legal system and state supervision (ILO, 2015). Unlike businesses on land that can easily monitor, capture fisheries business is difficult to apply sensitive protection standards to the fulfillment of workers' human rights (Adam, 2017). Based on the ILO report, every year, there are around 24 thousand fatal ship accidents and 24 million non-fatal accidents, or 79 times higher than the total rate of work accidents that occur in other work sectors. According to the International Maritime Organization (IMO), 80 percent of ship accidents occur due to human error, and for the capture fisheries industry, there is 7 percent of recorded accidents (Santara et al., 2014).

Meanwhile, the working and living conditions on commercial fishing vessels can be dangerous and unsanitary. Long working hours, limited protection from occupational hazards (Dharmawirawan \& Modjo, 2012), narrow and crowded living spaces are conditions that many capture fisheries workers face on board fishing vessels (Riantoro et al., 2018). Besides, exploitative treatment by senior workers and other workers often causes fishing vessels' workers to experience violence and heavy work pressure that leads to depression and death of workers.

Capture fisheries workers groups are human beings, absolute owners of human rights that have been universally recognized. Governments must understand that their rights, dignity, and security require specific and special protection. To anticipate and overcome the many human rights violations that occurred in Indonesian seas, the Government, through the Ministry of Marine Affairs and Fisheries, then issued a Regulation of the Minister of Marine Affairs and Fisheries Number 35 of 2015 concerning Fisheries Human Rights Systems and Certification (hereinafter Fisheries 
Human Rights Regulations), which refers to the United Nations Guiding Principles on Business and Human Rights (UNGP).

In the previous study, Kurnia Dwi Sulistiorin conducted research entitled Implementation of Human Rights Due Diligence in Limited Liability Companies in Indonesia (study at PT. Perikanan Nusantara). The study did not find any specific policies made by the company to implement the Human Rights Due Diligence rules. Besides, the study did not use fisheries' human rights certification rules in its analysis. Patricia Utami also conducted research entitled Efforts to Overcome Human Rights Violations in the Capture Fisheries Industry by Enforcing Human Rights Certification and Systems in terms of the United Nations Guiding Principles on Business and Human Rights: Studies on the Regulation of the Minister of Marine Affairs and Fisheries No. 35/PERMEN-KP/2015 concerning Systems and Certification of Human Rights in Fisheries Business. The research only focuses on juxtaposing Fisheries Human Rights Regulation Rules' suitability with the United Nations Guiding Principles on Business and Human Rights. While this study aims to examine how the provisions of the fisheries' human rights certification and conduct an analysis related to their impact on protecting human rights for fishing vessel crews in Indonesia. This research is expected to help the Government (Ministry of Marine Affairs and Fisheries, Ministry of Manpower), related observer activists, entrepreneurs, and the community to observe the regulations on fisheries human rights certification in Indonesia. This study's results are expected to find the effects and weaknesses of fisheries human rights certification rules in providing human rights protection for fishing boat crews, considering the formulation of more comprehensive fisheries human rights protection regulations.

\section{METHOD}

A method is a work procedure to understand the object in the target of the science concerned. A method is a guideline on how scientists learn and understand the steps they face (Soekanto \& Mamudji, 2015). According to Cholid Narbuko and Abu Achmadi, research is an activity to find, record, formulate and analyze to compile a research report (Budiono et al., 2018). The author uses a normative juridical research method by examining library materials or other secondary materials. The data collection method used is a literature study. The tools used are documents in the form of primary, secondary, and non-legal legal materials. The data obtained were analyzed qualitatively and then presented descriptively.

\section{RESULTS AND DISCUSSION}

\section{Human Rights Violations against Fishing Vessel Crew in Indonesia}

Based on reports from the ILO, commercial fishing is considered a very dangerous job with a very high accident and death rate in the world when compared to other types of work (Kolawole \& Bolobilwe, 2019). The shipping channel for fishing vessels is not like the shipping channel for commercial ships (Nakamura et al., 2018), because the fishing vessel shipping channel has to adjust the fishing area, which 
frequently moves; consequently, the scope of its working area will be very wide, even beyond the territorial boundaries of a country to the high seas (Greenpeace \& Serikat Buruh Migran Indonesia, 2019).

The increase in the recruitment of fishing vessel crews in Indonesia goes hand in hand with the increasing number of violence cases, abuse, bad working conditions, and slavery that befall them (Verite, 2016). The human rights violations that befell the vessel's crew are exacerbated by the fact that some are employed on vessels that carry out illegal, unreported, and unregulated fishing (IUU fishing) activities (Muhamad, 2016). In Indonesia itself, based on a report from the 2018 Global Slavery Index, it is revealed that at least 1,220,000 Indonesian citizens are trapped in the practice of modern slavery (Global Slavery Index, 2018). Unlike slavery during the era of imperialism and colonialism carried out roughly, cruelly, and arbitrarily, the modern practice of slavery is carried out in an invisible way to the perpetrators and victims as happened in the fishing, plantation, agriculture, and so on (Prisnasari, 2019).

The forms of modern slavery that also occur in the world of capture fisheries business in Indonesia include (Prisnasari, 2019):

1. human trafficking (trafficking in persons), is a series of events involving the transportation, recruitment, or hiding of people to exploit by using force, threats, or coercion.

2. Forced labor is coercing another person to do a job or any service with the threat of some form of punishment.

3. Debt Bondage or bonded labor is slavery that occurs when a person cannot pay a debt, so that person is required to work to pay off his debt.

4. Child slavery is slavery that occurs when a child is exploited for others' benefit, resulting in obstruction of the child's development and education.

5. Descent-based slavery (slavery based on heredity) is slavery that occurs because of heredity. A person is born a slave because their ancestors were enslaved.

One of the major cases related to slavery in Indonesia is the Benjina case revealed in 2015 (Darulzain et al., 2017). The Benjina case is a case that shows how poor human rights protection is for workers in the Indonesian fisheries sector. PT Pusaka Benjina Resources, which is domiciled in Indonesia, and three companies from Thailand, namely PT Silver Sea Fishery, PT Thai Hoang Huad, and PT Ocean Research Fishery, are the masterminds of Benjina's case. The three Thai companies act as vessel providers and capital injectors, while PT Pusaka Benjina Resources act as agents and field implementers. The crews in Benjina's case were tricked into paying high salaries. After being ordered to sign work contracts with no clear legal basis, they were sedated so that they could be taken easily to Benjina. When awakened, the crew members were already in Benjina, so they did not know where to go if they wanted to run away. They were employed under pressure, experienced violence, and were viewed and treated as slaves. The latest number of victims of Benjina slavery has reached nearly 550 people, most of them are Myanmar citizens. The discovery of a mass grave on Benjina Island, not far from the detention site, indicates that the real number of victims was more than recorded (Putri \& Utomo, 2019). 
Not long after the Benjina case was exposed, the Maritime and Fisheries Ministry's Anti-Mafia Illegal Fishing Task Force found a similar case in Ambon, Maluku. A total of 373 crew members became victims, and most of them were foreign crew members from Thailand, Cambodia, Laos, and Myanmar. 264 crew members have been repatriated to their countries of origin. Susi Pudjiastuti, as Minister of Fisheries and Marine Affairs, revealed that the Benjina case had a strong suspicion to have a connection with this case. The reason behind it is the parties involved in the Ambon Case are the same as the Benjina Case, plus the Canawi Group from Thailand and PT Mabiru Industries from Maluku (Darulzain et al., 2017).

In general, there are several problems of human rights violations that are most often experienced by fishing vessel crews in Indonesia, especially while carrying out their work on fishing vessels, namely:

1. Work without a Sea Work Agreement (Adam, 2017),

2. Violations related to working hours and rest periods (Robin McDowell et al., 2015),

3. Physical, psychological, and verbal abuse (Robin McDowell et al., 2015),

4. Sub-standard wages, wage deductions, and wages are not paid (Cahyadi, 2017)(M. Razi Rahman, 2019),

5. Facilities on board are sub-standard and inhuman (Nur, 2018),

6. Handling accident incidents on a modest vessel (Nur, 2018),

7. Access to legal aid is still very difficult (Nur, 2018),

\section{Human Rights Certification Arrangement for Human Rights, Protection for Fishing Vessel Crew.}

Protection of the human rights of workers in Indonesia must be implemented by every entrepreneur who employs people to work for the company as stated in the spirit of Pancasila and the 1945 Constitution of the Republic of Indonesia to guarantee basic rights of workers and guarantee equality and treatment without discrimination on any basis to realize the welfare of workers and their families while still paying attention to the development of the business sector and the interests of entrepreneurs. Protection of workers' human rights is the fulfillment of basic rights inherent and protected by the 1945 Constitution of the Republic of Indonesia. Theoretically, there are three types of work protection as a form of protection to human rights, especially in manpower itself; social, technical, and economic protection. This protection has been regulated in several laws and regulations, including:

- The 1945 Constitution of the Republic of Indonesia

- Law Number 39 of 1999 concerning Human Rights

- Law Number 11 of 2020 concerning Job Creation

- Law Number 13 of 2003 concerning Manpower

- Law Number 8 of 2017 concerning Protection of Indonesian Migrant Workers

- Law Number 01 of 1970 concerning Work Safety

- Law Number 21 of 2000 concerning Worker Unions

- Law Number 40 of 2004 concerning the National Social Security System 
- Government Regulation Number 78 of 2015 regarding Wages, etc.

The Benjina and Ambon cases opened the Government's eyes that human rights violations were very vulnerable to occur in fisheries. The Government of Indonesia, through the Ministry of Marine Affairs and Fisheries announced the enforcement of Regulation of the Minister of Marine Affairs and Fisheries of the Republic of Indonesia Number 35/PERMEN-KP/2015 concerning Human Rights Certification and Systems in Fisheries Business (Fisheries Human Rights Regulations) to prevent human rights violations by third parties, especially business actors, in the Indonesian fishery sector. To complement the Fisheries Human Rights Regulations, the Ministry of Marine Affairs and Fisheries then issued the Minister of Marine Affairs and Fisheries Regulation Number 2/PERMEN-KP/2017 concerning Requirements and Mechanisms for Fisheries Human Rights Certification. Regulation of the Minister of Marine Affairs and Fisheries Number 35/Permen-KP/2015 was signed on Human Rights Day in 2015. The follow-up regulation is Regulation of the Minister of Marine Affairs and Fisheries Number 2/Permen-KP/2017 concerning Requirements and Mechanisms for the Human Rights Certification of Fisheries were announced at the International Conference on the Protection of Human Rights in the Fishery Industry in January 2017. The two regulations form a fisheries human rights certification system. The Fisheries Human Rights Regulations require fisheries entrepreneurs to implement a company-level compliance scheme consisting of three elements: (1) Establishment of a broad human rights policy; (2) Mechanisms to facilitate due diligence; and (3) Remediation mechanism.

Fisheries Human Rights Regulations are the first rules issued by the Government for the protection of human rights in the fisheries sector, as well as the first rules in Indonesia to encourage the implementation of respect for human rights as stipulated in the United Nations Guiding Principles on Business and Human Rights (UNGP). The Fisheries Human Rights Regulations will require everyone, both Indonesian citizens and foreign nationals, including business actors such as fishery entrepreneurs who carry out fishery business activities in the territory of the Republic of Indonesia, to respect the human rights of parties related to fishery business activities, including fishing vessel crews and local communities. In essence, the Fisheries Human Rights Regulations provisions are under UNGP's Basic Principles 1 Pillar I.

Fisheries Human Rights Regulations require employers to implement a fisheries human rights system consisting of a human rights policy, human rights due diligence, and human rights restoration. Human rights policies are made in the form of a commitment statement to comply with all laws and regulations. Meanwhile, human rights due diligence is a process carried out by fishery entrepreneurs to identify, assess, prevent, mitigate, and overcome the impact of human rights violations arising from fishery entrepreneurs' activities, operations, and business relationships. Furthermore, human rights restoration is a process that aims to resolve the impact of human rights violations caused or participated by fishery entrepreneurs through an effective judicial and non-judicial complaint mechanism. 
The first human rights system is related to human rights policies. Fisheries Human Rights Regulations stipulate that human rights policies are made in a commitment statement to comply with all applicable laws and regulations. The commitment statement at least contains the Fishery Entrepreneur's commitment to:

1. respect the human rights of parties affected by human rights violations related to fishery business activities;

2. respect the right to fair and decent working conditions, including the right to:

a. adequate and satisfy remuneration and rest periods;

b. a decent standard of living, including accommodation, food, and drink;

c. get treatment;

d. get social security insurance;

e. get protection from work risks; and

f. special rights of women, children, and persons with disabilities.

3. apply sea work agreement for workers and sea work agreement for the crew of fishing vessels with appropriate wage standards;

4. avoiding forced labor, among others in the form of:
a. abuse of vulnerability;
b. fraud;
c. space restrictions;
d. exile;
e. physical and sexual violence;
f. intimidation and threats;
g. detention of identity documents;
h. withholding wages;
i. debt bondage;
j. torturous working and living conditions; and
k. excessive overtime work.

5. carry out Human Rights Due Diligence;

6. to restore human rights; and

7. provide training on the Fisheries Human Rights System to Fishing vessel Workers and Crew in a sustainable manner.

The commitment statement referred to above is then obliged to be signed by the Fishery Entrepreneur or its authorized representative, socialized to and available to the public, and serve as a reference in the formulation of company policies and operational procedures.

In implementing Human Rights Due Diligence, Fishery Entrepreneurs must fulfill the following criteria for fisheries human rights compliance:

1. Fishery business occupational safety and health, at least in the form of:

a. availability of procedures to ensure occupational safety and health;

b. availability of occupational safety and health experts;

c. availability of adequate accommodation and adequate nutrition of workers and crew of fishing vessels; 
d. fulfillment of work equipment and equipment requirements for fishery entrepreneurs to ensure occupational safety and health; and

e. implementation of safety and health training for workers and crew of fishing vessels.

2. The recruitment system for Fishing Vessel Workers and Crew, at least in the form of:

a. procedures ensuring the recruitment of Fishing Vessel Workers and Crew;

b. fulfillment of minimum age and competency requirements for Fishing Vessel Workers and Crew; and

c. application of work agreements and sea work agreements.

3. Manpower system, at least in the form of:

a. fulfillment of requirements for collective labor agreements or company regulations;

b. fulfillment of occupational health and accident insurance for workers; and

c. fulfillment of social security requirements.

4. Responsibility for sustainable community development, at least in the form of:

a. creation of employment opportunities for the surrounding community; and

b. increasing the standard of living of the surrounding community.

5. Security system, at least in the form of:

a. conducting human rights training for security personnel; and

b. integration of human rights elements in security work procedures.

6. Environmental management system, at least in the form of:

a. prevention of environmental pollution; and

b. maintenance of biodiversity.

7. Land acquisition system, at least in the form of:

a. fulfillment of requirements to avoid forced expropriation of land; and

b. fulfillment of the requirements for a reasonable replacement.

Furthermore, in implementing human rights restoration, fishery entrepreneurs are required to implement an effective mechanism and cooperate in other legal processes to ensure the resolution of the impact of human rights violations from the operations and business relations of fishery entrepreneurs. The implementation of human rights recovery will certainly have a profound impact on every individual fishing vessel crew who has experienced human rights violations in the form of fulfilling the rights to wages, restoring the impact of workplace violence, and restoring work accidents. This human rights system is expected to be a form of human rights protection from the Government and proof of respect for fishery entrepreneurs' human rights. Through the Fisheries Human Rights Regulations, ideally, every fishery entrepreneur must comply with the Human Rights System on paper and implement it. After the fishery entrepreneur implements the entire fishery human rights system and is declared to have passed the human rights certification, the Minister will issue a human rights certificate to the fishery entrepreneur.

This fisheries human rights certificate has three years' valid period. Based on the Minister's delegation of authority, the Fisheries Human Rights Team Head will issue a 
Human Rights certificate. This certification procedure begins with the fulfillment of the Fisheries Human Rights System by fisheries entrepreneurs, who then make a letter requesting the implementation of the fisheries human rights certification appraisal to the head of the fisheries human rights team. After that, the Fisheries Human Rights Team head will appoint an Assessment Agency, but the Fisheries Human Rights Team will carry out the assessment if it is not there.

The Application Letter is then verified by the Head of the Fisheries Human Rights Team no later than 7 (seven) working days after the documents are complete. They will then determine whether the application is rejected because it is incorrect, returned because it is incomplete, or human rights certification assessment can be carried out. If an assessment can be carried out, the Fishery Entrepreneur makes a work contract with the Appraisal Agency, and then the Appraisal Agency will carry out its duties. The assessment is carried out based on the documentation of the Fisheries Human Rights System results, field monitoring, and interviews. The final result of the report is conformity and non-conformity. If the result is conformity, the Appraisal Agency will recommend the issuance of a fisheries human rights certificate to the Head of the Fisheries Human Rights Team. After that, the Fisheries Human Rights Team will verify that a Human Rights Certificate will be issued if it is complete and correct.

There are several forms of protection for fishing vessel crews which are important points in the regulation of Fisheries Human Rights Regulations, including:

1. Protection of Human Rights at the Recruitment Stage

To ensure the fulfillment of protection for fishing vessel crews during the recruitment process, the Fisheries Human Rights Regulations regulates the recruitment standards for crew members who are considered to comply with human rights standards for fishing vessel crews. This provision is contained in the attachment of the Fisheries Human Rights Regulations. The attachment states that Fishery Entrepreneurs must have a Standard Operating Procedure (SOP) regarding the recruitment of Fishing Vessel Crew and Workers which regulates that:

a. an authorized institution must carry out recruitment of fishing vessel crew as a fishing vessel crew agency company that has a permit from the ministry of manpower;

b. recruitment fees are not borne by Fishing vessel Crew and/or Workers;

c. work agreements for fishing vessel crews and/or workers must be made fairly, transparently, without discrimination, and in a format and language that is easy to understand and must be signed by all parties;

d. fishing Vessel Crew may not use outsourced labor;

e. all Fishing Vessel Crew and/or Workers can become members of a legal and recognized trade union;

f. marine Work Agreement documents are kept by the Fishery Entrepreneur and held by each Fishery Ship Crew and/or Worker, and Fishing Vessel Crew Agency companies must be legally registered with the Ministry of Marine Affairs, and Fisheries as the distributor for Fishery Vessel Crew. 
Besides, Fishery Entrepreneurs are also required to determine the requirements for fishing vessel crews who are at least:

a. has a certificate of shipping safety competence (seaworthy), operational safety competence in fishing (fit to be caught), competency in the safety of fishery products (fit for storage) issued by the competent authority by the position and expertise required;

b. determine the minimum age for work, namely 18 years;

c. be Indonesian citizenship, or allowed to have a limited foreign nationality for a certain position and time limit by the labor laws and regulations regarding the procedures for the use of foreign workers and immigration regulations;

d. before working on a vessel, the crew of a fishing vessel must receive pre-sea training;

e. every fishing vessel crew must be listed in the certificate book and crew list; and

f. other than fishing vessel crew (cadets or apprentices, and observers) must be listed in a separate list.

2. Protection of Human Rights Related to Marine Work Agreements

By the mandate of the law, composing a Marine Work Agreement must be made in an authentic form, not an underhand deed. It is regulated in the second book of the KUHD, Government Regulation No. 7 of 2000 concerning Maritime Affairs and Law Number 17 of 2008 concerning Shipping, which is a special law (lex specialist) that overrides general laws (lex generalist), also in the third book of Chapter VII.A of the Civil Code and Law Number 13 of 2003 concerning Manpower. Article 399 of the KUHD explicitly imposes a Sea Work Agreement on the employer. In contrast, Article 400 letter (d) requires making a Sea Work Agreement in an authentic form by being ratified by a State official, namely Syahbandar (Balik, 2016).

One of the human rights policy requirements is a commitment to agreeing and implementing a work agreement for fishing vessel crews. Employers' obligation to compose and comply with the Sea Work Agreement is regulated in Article 5 Paragraph (2) letter c Fisheries Human Rights Regulations. The Fisheries Human Rights Regulations have determined the standard contents that must contain in a Sea Work Agreement, namely: the jurisdiction of the Sea Work Agreement; legal certainty of Sea Work Agreement; working conditions and conditions on board fishing vessels; age; health standards; competence of fishing vessel crews; competency certificate; competent authority; fishing vessel crew documents; rights and obligations; hours of work, leave and work permit; insurance coverage; accommodation, food and drink; return; Remuneration; standard wage payment system; signing and validity period; termination of employment by force majeure; placement of fishing vessel crew; dispute resolution and advocacy; Sea Work Agreement material; and sanctions. The Sea Work Agreement must be checked and authorized by the harbormaster at the fishing port.

Therefore, to implement this commitment and regulate more specifically related to Sea Work Agreement, the Minister of Marine Affairs and Fisheries then stipulates 
Regulation of the Minister of Marine Affairs and Fisheries Number 42/PermenKP/2016 concerning Marine Work Agreements for Fishing Vessel Crew. This regulation has been in effect since 2016 with the stipulation of detailed requirements regarding the obligation to have a Sea Work Agreement.

3. Protection of Human Rights related to Occupational Health and Safety (OHS)

The previous sub-section explanation has explained that one of the problems often faced by fisheries crew members is safety and health working on board problem, one of which is caused by accidents. An accident is an event that is naturally uncertain, because it cannot be predicted when it will occur, where it will take place, and the amount or size of the losses incurred. So that people often think that the accident is related to someone's fate. The accident is always preceded by symptoms that indicate an accident. In other words, the cause of the accident can be found (Kalu et al., 2018).

Many factors can increase the risk of accidents, including conditions of relatively long working hours that cause fatigue; the condition of the ship is old and poorly maintained; narrow workspace; occupational hazards (such as weather conditions); less skilled and less training; lack of monitoring and performance of ship engines; hazardous handled products such as poisonous fish; lack of equipment and use of safety equipment, and other factors that ultimately threaten the safety of the crew who work on the ship and lead to neglect of their rights in terms of compensation and insurance. Therefore, regulation of the standards for the protection of occupational health and safety as well as prevention of work accidents for fishing vessel crews on board has become an absolute thing to do. According to the ILO, one type of work has a high risk of accidents, it requires every party to provide more protection for workers in this field. One form of material regulation is regulated in the 2007 Work in Fishing Convention as outlined in Articles 29 to 33.

Apart from occupational safety, occupational health is also the most important thing and goes hand in hand in carrying out work on fishing vessels. ILO has included these health requirements as essential to be met in international instruments related to this field of work. The provisions in Article 10 of the Work in Fishing Convention 2007 state:

a. No crew members work on a fishing vessel without a valid medical certificate certifying that they are fit to carry out their duties.

b. The competent authority may, after consultation, grant exemptions from the application of paragraph 1 of this Article, taking into account the safety and health of the crew, size of the vessel, availability of medical and evacuation assistance, time of the voyage, the field of operation and the type of fishing activity.

c. The exception in paragraph 2 of this Article does not apply to crew members who work on fishing vessels that are 24 meters in length or more or who usually remain at sea for more than three days. In an emergency, the competent authority may permit the crew to work on the ship for a limited time or for a 
specified time until the medical certificate can be obtained. The crew member has a medical certificate that has expired by the most recent date.

Furthermore, the elucidation in Article 11 and Article 12 of this convention also emphasizes the regulation of such medical certificates. Article 11 provides that each Member State will implement laws, regulations, or other measures concerning:

1. the nature of the medical examination;

2. form and content of medical certificates;

3. issue of a medical certificate by a qualified medical practitioner or, if the certificate relates only to vision, by a person recognized by the competent authority as eligible to issue the certificate; then they are completely free to give their professional judgment;

4. the frequency of medical examinations and the period of validity of the medical certificate;

5. the right to further examination by another independent medical practitioner if a person's certificate has been denied or has limited the work he can do; and

6. other related requirements.

Then Article 12 explains that in addition to the requirements stipulated in Article 10 and Article 11, for fishing vessels with a length of 24 meters or more, or for vessels which usually remain at sea for more than three days, then:

1. The crew's medical certificate must, at a minimum, state that:

a. the crew's hearing and sight are satisfactory for carrying out their duties on board; and

b. the crew does not suffer from a medical condition that would likely be interfered with by work at sea or render the crew incapable of such duties or endanger others' safety or health on board.

2. The medical certificate must be valid for a maximum period of two years unless the crew members are less than 18 years of age, for which the maximum period of validity is one year.

3. If the certificate's validity period ends while sailing, the certificate will remain in effect until the end of the voyage.

This has also been realized by the Ministry of Marine Affairs and Fisheries based on various cases that have occurred, so that regulations related to occupational safety and health are included in the Fisheries Human Rights Regulations. Occupational safety and health itself aim to minimize or eliminate potential hazards or risks that may result in illness and accidents and possible losses. In fact, Fisheries Human Rights Regulations have included provisions regarding employers' obligation to provide occupational safety and health protection for the crew of fishing vessels they employ. In the Fisheries Human Rights Regulations, it is stipulated that fisheries entrepreneurs must have a Standard Operating Procedure (SOP) on hazard identification, risk assessment, and risk control to ensure that OHS risks that have or will emerge can be controlled. In addition, fisheries entrepreneurs are also required to have an SOP on health to ensure:

1. Fishing Vessel Crew to be recruited have a health certificate; 
2. Fishery Entrepreneurs have regular health inspection procedures for Fishing Vessel Crew and/or Workers;

3. Fishery Entrepreneur has appointed a hospital that meets the requirements stipulated by the Fishery Entrepreneur or another hospital that meets the requirements in an emergency; and

4. There are fishing vessel crews and/or workers who have certification and the ability to act as first aid officers in work accidents who can provide instructions on the use of medical equipment and medicines.

Fishery Entrepreneurs must have an SOP regarding accommodation to ensure the availability of adequate accommodation for Fishing Vessel Crew during fishing operations provided that:

1. Fishery Entrepreneurs provide food and beverage accommodation supplies with sufficient quality and quantity during fishing operations and the crew of fishing vessels are not charged for that); and

2. The food and drink provided must meet the standards of nutritional value and hygiene.

The Fisheries Human Rights Regulations also stipulate that Fisheries Entrepreneurs must have an SOP on safety equipment and equipment with the following requirements:

1. Provided free of charge, all required work safety equipment, and equipment for Fishing Vessel Crew and/or Workers in accordance with the predefined hazard identification risk assessment; and

2. Provided for every other person who enters the workplace, accompanied by instructions required according to the safety supervisor

The previous sub-discussion explanation also explained that there were many cases of accidents occurred on fishing vessels such as crushed fingers on conveyer belts, being hit by fish preservatives, injuries, and others, where in some reports of accidents were only handled improperly with non-medication. Adequate on board. These facts also become one of the issues used as the basis for regulations related to first aid standards in fishing vessels' accidents. The Fisheries Human Rights Regulations stipulates that fisheries entrepreneurs must have a first aid SOP to ensure:

1. The availability of equipment and medicines for health assistance/work accidents on ships and/or fish processing units, the number of which is adjusted to the crew of the fishing vessel and/or workers, fishing ground (operational area), and the period of fishing and/or fish processing operations; and

2. Availability of work instructions understood by fishing vessel crews and/or workers regarding equipment and medicines for health assistance/work accidents on vessels/fishery business environment.

3. Protection of Human Rights Related to Freedom of Opinion and Association 
Freedom of opinion and association has been guaranteed in the Indonesian constitution. Article 28 E Paragraph (3) of the 1945 Constitution states that "everyone has the right to freedom of association, assembly, and expression of opinion". Article 24 Paragraph (1) of Law No. 39 of 1999 concerning Human Rights also affirms that everyone has the right to assemble, hold meetings, and associate for peaceful purposes. This freedom within the scope of manpower is also regulated in Article 104 Paragraph (1) of Law Number 13 Year 2003 concerning manpower which states that "Every worker/laborer has the right to form and become a member of a trade/labor union." Then, specifically also regulated in Article 5 (1) of Law no. 21 of 2000 concerning Trade Unions/Labor Unions, that every worker/laborer has the right to form and become a member of a trade/labor union. This right is then also accommodated in the Fisheries Human Rights Regulations, where one of the indicators for assessing human rights compliance is the existence of a Collective Labor Agreement agreed upon by fisheries entrepreneurs and trade unions.

\section{Weaknesses of Human Rights Certification in Protecting Human Rights for Capture Fishing Vessel Crew}

Based on the results of the study and analysis of the author, there are several weaknesses in the regulation and application of Fisheries Human Rights Certification for the protection of fishing vessel crews, including:

1. Weaknesses in Wage System Arrangements

There has been no authoritative figure set by the Government of Indonesia, which regulates a certain minimum wage standard for fishing vessel crews. Unfortunately, the minimum wage standard for fishing vessel crews is not regulated in the Fisheries Human Rights Regulations. The Fisheries Human Rights Regulations only states that the wage system and standards for fishing vessel crews refer to the prevailing laws and regulations. Thus, until now, the minimum wage standard applied for fishery vessel crews has been equated with the provincial minimum wage standard (UMP) or the district minimum wage standard (UMK). A fishing vessel crew is a different profession from other jobs, because it has a very high risk. Jobs on fishing vessels are generally dangerous because they catch (hunt) fish in the sea with erratic environmental conditions (weather) with high work risks. Considered difficult because not everyone can work using various types of fishing gear, and not everyone can live on a vessel at sea, and dirty because fishing vessels handle perishable fish directly. Thus, the Government should have made a wage standard for this job sector that is different and higher than other jobs. Apart from the wage system, in many areas, employers also apply a profit-sharing scheme. In many cases and several previous research results, fishing vessel crews did not have the right to provide input regarding the profit-sharing amount's determination. Entrepreneurs/ship owners will provide offers that make crew members interested in working on their ships (Widihastuti \& Rosyidah, 2018). Owners or entrepreneurs usually give the crew of the vessel an attractive profit-sharing lure to be willing to work on their ships. Another mode that often ensnares ship crews is before going to sea, the entrepreneur/ship owner will usually ask if the crew wants 
to be given a loan for the family to be left behind. During the peak fishing season, the skipper will offer several loan options (can be in the form of money, or new vehicles) to bind the crew to continue working for the ship's skipper (Pratama et al., 2016). The payment of the debt of the crew is then taken from the salary or profit-sharing system obtained. So, like it or not, the ship members are then bound to the entrepreneurs/ship owners to continue working for them until their debt is paid off.

2. Limited Target of Fisheries Human Rights Regulations

Fisheries Human Rights Regulations indicate a link between certification and denial of fishing permits or labor permits. However, there does not appear to be a form of "coercion" policy for entrepreneurs to carry out certification in practice in the field. The threat of delaying or revoking fishing permits by the Ministry of Marine Affairs and Fisheries is only relevant to about $10 \%$ of the Indonesian fishing fleet, which is only for fishing vessels over 30 GT, because the enforcement of fishing permits is only intended for vessels of this size. In addition, a permit to use labor from the Ministry of Manpower is irrelevant for fishery entrepreneurs involved in the preproduction, production, processing, and marketing of fishery products.

3. The involvement of representatives of workers and employers in the Fisheries Human Rights Team is not clear.

The Fisheries Human Rights Team is a form of protection and respect for human rights from the state through the Minister for the fisheries industry. The Fisheries Human Rights Team consists of various agencies, namely elements from the ministry, non-ministerial government agencies, and related non-governmental organizations that is formed in a transparent, participatory, and accountable manner. Therefore, the Fisheries Human Rights Team should also come from representatives of workers and representatives of employers to provide a real picture of the problems faced in the fishing industry that occur in the field. However, the Fisheries Human Rights Regulations and Regulation of the Minister of Marine Affairs and Fisheries Number 2/Permen-KP/2017 concerning Requirements and Mechanisms for Fisheries Human Rights Certification do not provide clear space for these two representatives as part of the structure of the Fisheries Human Rights Team.

4. Weaknesses of the Coordinating System for the Fisheries Human Rights Team and the Labor Inspector

The regulation of the labor system in Indonesia is generally under the authority of the Ministry of Manpower. One of the structures formed in the supervision framework related to compliance with laws and regulations in the manpower sector is the Labor Inspector. However, the absence of a coordination mechanism with Labor Inspectors when labor violations are found in the Fisheries Human Rights assessment and certification process creates significant gaps in the Fisheries Human Rights certification system. It can undermine both the private compliance initiative developed by the CTF and labor inspection under the Ministry of Manpower in the presence of two parallel systems with oversight of two ministries. Without complementary 
coordination, the fisheries' human rights certification system can weaken labor inspectors' role, as it will appear that there will be a monopoly on labor enforcement in the fisheries and seafood sectors. The Fisheries Human Rights Team seems to have replaced the Labor Inspectorate role with a private appraisal agency, even though the agency has been accredited.

Then, referring to the Fisheries Human Rights Regulations, it is stipulated that Human Rights Certification is given after passing the standardized legal document due diligence process as well as field monitoring. Fish entrepreneurs who have passed the Fisheries Human Rights Certification can use the Human Rights Certification for 3 (three) years. However, after obtaining Human Rights Certification, the Fisheries Human Rights Regulations provisions do not explain the periodic monitoring mechanism regarding the Fishery Entrepreneur's compliance progress.

5. Weaknesses of Fisheries Human Rights Assessment Institutions in Indonesia

The fisheries human rights certification procedure begins with the fulfillment of the fisheries human rights system by fisheries entrepreneurs, who then make a letter requesting the implementation of the fisheries human rights certification assessment to the head of the fisheries human rights team. After that, the Fisheries Human Rights Team's head will appoint an Assessment Agency, but the Fisheries Human Rights Team will assess if it is not there. Unfortunately, there are not many Assessment Bodies that focus on Indonesia's marine and fisheries sector, and not many of the existing Assessment Bodies are competent and accredited. Most Assessment Bodies in Indonesia focus on Audit and Management Institutions in general, even though the assessment bodies for Fisheries Human Rights Certification must fully understand the fishing industry's core business to fully understand the challenges and problems faced by workers and employers.

6. Weaknesses of Socialization for Employers and Workers

Article 5 Paragraph (1) Fisheries Human Rights Regulations stipulates that fishery entrepreneurs must first apply a human rights system to fisheries business to obtain a fisheries human rights certificate. This Article's provisions automatically force entrepreneurs to understand the human rights criteria referred to in the regulation. Whereas for fisheries entrepreneurs, the term Fisheries Human Rights Certification is a term that is rarely heard, let alone how the concept is implemented in fisheries business. Therefore, before being directed to obtain Human Rights Certification, the most important thing to do is provide education about human rights basics in the capture fisheries business, both for entrepreneurs and workers/crew. This concept will then be more easily understood by all parties, not only for the regulators.

In 2019, the Ministry of Marine Affairs and Fisheries, in this case, the Fisheries Human Rights Team, has provided training to capture fisheries entrepreneurs in several regions in Indonesia. However, what becomes a critical note is that the training is only intended for fishery entrepreneurs, vessel crews, and other fishery workers who are completely not involved. Workers are very important to understand the provisions of their rights, which are regulated in this Fisheries Human Rights Certification system. 
Understanding of workers will be able to increase their awareness of their rights and mechanisms for reporting violations they experience. Another note is that the training carried out by the Fisheries Human Rights Team only focuses on training the preparation of documents required for the assessment of Fisheries Human Rights Certification. In fact, the main focus should be how to make entrepreneurs understand their obligations and encourage the implementation of these obligations to crew members and other workers in the field.

\section{CONCLUSION}

Human rights violations against fishing vessel crews in Indonesia have been frequent so far. One of the major cases related to slavery in Indonesia is the Benjina case revealed in 2015. There are several forms of protection for fishing vessel crews which are important points in the regulation of Fisheries Human Rights Regulations, including protection of human rights at the recruitment stage, protection of human rights related to marine work agreements, protection of human rights related to occupational safety and health, and protection of human rights related to freedom of opinion and association. Based on the results of the author's study and analysis, judging from its content, Fisheries Human Rights Regulations should impact the protection of fisheries workers' human rights, but in fact, this impact is unseen. It is due to weaknesses in these regulations, including weaknesses in Wage System Arrangements, Very Limited Target Fisheries Human Rights Regulations, Involvement of Worker and Employer Representatives in the Fisheries Human Rights Team has not Clearly, the weaknesses of the coordination system between the fisheries human rights team and labor inspectors, weaknesses of fisheries human rights assessment institutions in Indonesia, weaknesses of socialization for employers and workers.

\section{ACKNOWLEDGMENTS}

Thank you, the writer conveyed to the Rector of Universitas Ahmad Dahlan, Dr. Muchlas, M.T., and all parties who helped complete this service report, which cannot be mentioned one by one.

\section{REFERENCES}

Adam, L. (2017). Kebijakan Perlindungan Pekerja Perikanan Tangkap Indonesia. Kajian, 21(4), 321-338. https://doi.org/10.22212/KAJIAN.V21I4.782

Balik, A. (2016). Tanggungjawab Pengusaha Pelayaran Dalam Perjanjian Kerja Laut (PKL) Terkait Dengan Jam Kerja. Jumal Sasi, 22(2), 12-20. https://fhukum.unpatti.ac.id/jurnal/sasi/article/view/164/75

Budiono, A., Izziyana, W., \& Santoso. (2018). Konsep Etik Perlindungan Hukum Terhadap Profesi Guru. Justitia Jurnal Hukum, 2(2), 224-233. http:/ journal.umsurabaya.ac.id/index.php/Justitia/article/view/2237

Cahyadi, T. (2017). Perlindungan Hukum Pelaut di Kapal Indonesia Berbasis Nilai Keadilan. Jurnal Pembaharuan Hukum, 4(1), 97. https://doi.org/10.26532/jph.v4i1.1652

Darulzain, M. R., H. M. Kabul Supriyadhie, \& Rahayu. (2017). Penerapan Foundational 
Principles Of The State Duty To Protect Human Rights Dalam United Nations Guiding Principles On Business And Human Rights (UNGP) (Studi terhadap Perlindungan HAM Pekerja di Sektor Perikanan Indonesia). Diponegoro Law Journal, $\quad 6(2), \quad$ 1-16. https://ejournal3.undip.ac.id/index.php/dlr/article/view/19577/18568

Dharmawirawan, D. A., \& Modjo, R. (2012). Identifikasi Bahaya Keselamatan dan Kesehatan Kerja pada Penangkapan Ikan Nelayan Muroami. Kesmas: National Public Health Journal, 6(4), 185. https://doi.org/10.21109/kesmas.v6i4.98

Global Slavery Index. (2018). The Global Slavery Index 2018. https://downloads.globalslaveryindex.org/ephemeral/GSI2018_FNL_190828_CO_DIGITAL_P-1603460367.pdf

Greenpeace, \& Serikat Buruh Migran Indonesia. (2019). Seabound: The Journey To Modern Slavery On The High Seas.

ILO. (2015). International Expert Meeting on Labour Exploitation in the Fishing Sector in the Atlantic.

http://www.ilo.ch/wcmsp5/groups/public/@ed_norm/@declaration/docum ents/publication/wcms_429048.pdf

International Labour Organization. (2013, September 13). Pertemuan untuk mengkaji upaya perlindungan pekerja perikanan di kawasan ASEAN. https://www.ilo.org/asia/media-centre/news/WCMS_221452/lang-en/index.htm

Kalu, Y., Kaparang, F. E., \& Modaso, V. O. J. (2018). Studi tentang kesehatan dan keselamatan kerja di atas kapal pole and line yang berpangkalan di Aertembaga Bitung (Study on health and safety on pole and liner based in Aertembaga Bitung). Jurnal Ilmu Dan Teknologi Perikanan Tangkap, 2(6). https://doi.org/10.35800/jitpt.2.6.2017.17000

Kolawole, O. D., \& Bolobilwe, K. (2019). Survival at a cost: how artisanal fishers perceive occupational hazards in the Okavango Delta, Botswana. South African Geographical Journal, 101(1), 51-71. https://doi.org/10.1080/03736245.2018.1541019

M. Razi Rahman. (2019, October 29). LSM Temukan Masih Ada Awak Kapal Ikan Digaji di Bawah Upah Minimum. https://www.antaranews.com/berita/1136492/lsmtemukan-masih-ada-awak-kapal-ikan-digaji-di-bawah-upah-minimum

Muhamad, S. V. (2016). Illegal Fishing di Perairan Indonesia: Permasalahan dan Upaya Penanganannya Secara Bilateral di Kawasan. Jurnal Politica Dinamika Masalab Politik Dalam Negeri Dan Hubungan Internasional, 3(1), 59-85. https://doi.org/10.22212/JP.V3I1.305

Nakamura, K., Bishop, L., Ward, T., Pramod, G., Thomson, D. C., Tungpuchayakul, P., \& Srakaew, S. (2018). Seeing Slavery in Seafood Supply Chains. Science Advances, 4(7), e1701833. https://doi.org/10.1126/sciadv.1701833

Nur, M. (2018). Recommendation for Authorization Overlaping of Placement of 
Indonesian Fishing Vessels Crews Abroad. Jurnal IUS Kajian Hukum Dan Keadilan, 6(1), 1. https://doi.org/10.29303/ius.v6i1.532

Pratama, M. A. D., Hapsari, T. D., \& Triarso, I. (2016). Faktor-Faktor Yang Mempengaruhi Hasil Produksi Unit Penangkapan Purse Seine (Gardan) di Fishing Base PPP Muncar, Banyuwangi, Jawa Timur. Jurnal Saintek Perikanan, 11(2), 120. https://doi.org/10.14710/ijfst.11.2.120-128

Prisnasari, I. (2019). Modern Slavery Pada Anak Buah Kapal (Abk) Perikanan Dalam Perspektif Hak Asasi Manusia. Jurist-Diction, 2(2), 475. https://doi.org/10.20473/jd.v2i2.14229

Putri, D. A. A., \& Utomo, T. C. (2019). Kerjasama International Organization for Migration (IOM) dan Pemerintah Indonesia dalam Menangani Perdagangan dan Perbudakan Manusia di Industri Perikanan PT. Pusaka Benjina Resource Tahun 2015. Journal of International Relations, 5(1), 998-1006. http://ejournals1.undip.ac.id/index.php/jihiWebsite:http://www.fisip.undip.ac.id/

Riantoro, M. R., Iskandar, B. H., \& Purwangka, F. (2018). Potensi Kecelakaan Kerja pada Perikanan Bagan Apung di PPN Palabuhanratu, Jawa Barat. Jurnal Teknologi Perikanan Dan Kelautan, 8(2), 221-236. https://doi.org/10.24319/jtpk.8.221-236

Robin McDowell, Margie Mason, \& Martha Mendoza. (2015). AP Investigation: Slaves may have caught the fish you bought Associated Press. https://www.ap.org/explore/seafood-from-slaves/ap-investigation-slaves-mayhave-caught-the-fish-you-bought.html

Santara, A. G., Purwangka, F., \& Iskandar, B. H. (2014). Peralatan Keselamatan Kerja Pada Perahu Slerek Di PPN Pengambengan, Kabupaten Jembrana, Bali. Jurnal IPTEKS PSP, 1(1), 53-68.

Soekanto, S., \& Mamudji, S. (2015). Penelitian Hukum Normatif: Suatu Tinjauan Singkat (17th ed.). Rajawali Pers.

Suwardjo, D., Haluan, J., Jaya, I., \& Poernomo, S. H. (2017). Kajian Tingkat Kecelakaan Fatal, Pencegahan dan Mitigasi Kecelakaan Kapal-Kapal Penangkap Ikan yang Berbasis Operasi Di PPP Tegalsari, PPN Pekalongan dan PPS Cilacap. Jurnal Teknologi Perikanan Dan Kelautan, 1(1), 61-72. https://doi.org/10.24319/jtpk.1.61-72

Verité. (2016). Fishing and Aquaculture, Overview of the Fishing and Aquaculture Sector. http://www.worldwildlife.org/industries/farmed-seafood

Widihastuti, R., \& Rosyidah, L. (2018). Sistem Bagi Hasil Pada Usaha Perikanan Tangkap di Kepulauan Aru. Jurnal Kebijakan Sosial Ekonomi Kelautan Dan Perikanan, 8(1), 63. https://doi.org/10.15578/jksekp.v8i1.6859

Wijaya, R. A., \& Firdaus, M. (2016). Sistem Perekrutan Pekerja dan Hubungan Kerja pada Usaha Perikanan Tuna. Jurnal Kebijakan Sosial Ekonomi Kelautan Dan Perikanan, 4(1), 1. https://doi.org/10.15578/jksekp.v4i1.28 